\title{
Comparison of two tagging techniques for Sarpa salpa: external attachment and intraperitoneal implantation
}

\section{Comparaison de deux techniques de marquage pour Sarpa salpa: attachement externe et implantation intrapéritonéale}

\author{
Catherine Jadot* \\ University of Liege, Department of Eco-ethology, Quai Van Beneden, 22, 4020 Liege, Belgium
}

Received 26 November 2002; received in revised form 26 February 2003; accepted 24 March 2003

\begin{abstract}
For a given species in a particular environment, the success and the harmlessness of transmitter attachment appear to be highly specific. As no information was available for the tagging of the strepie, Sarpa salpa, a suitability study of attachment techniques was needed. Two types of transmitter attachments were investigated: (1) externally, placed on the back of the fish below the dorsal fin by means of two threads sutured through the dorsal musculature, and (2) internally, in the peritoneal cavity. Twenty-five fish were monitored over a 14-d period for survival, surgical healing, injury occurrence and post-tagging behaviour. Even though we observed a 100\% survival rate for both groups, with no noticeable buoyancy or swimming alteration, findings from this study indicate that both groups of tagged fish were affected by the presence of the transmitter in different ways. Fish with an external transmitter were chronically affected, incurring physical impact, whereas the surgically-implanted fish exhibited short-term tagging effects (less than $36 \mathrm{~h}$ ), attributable to surgery effects, and were not subject to fouling on transmitter or wound chafing. Moreover, they appeared to recover quickly with no indication of long-term effects. Based on the findings of this study, the use of the surgical implantation method for Sarpa salpa is recommended.
\end{abstract}

(C) 2003 Éditions scientifiques et médicales Elsevier SAS and Ifremer/CNRS/IRD. All rights reserved.

\section{Résumé}

Pour une espèce donnée dans un environnement particulier, le succès d'attachement d'un émetteur s'avère hautement spécifique. Aucune information n'étant pour le moment disponible pour le marquage de la saupe, Sarpa salpa, un étude de faisabilité des techniques d'attachement d'émetteurs était nécessaire. Deux types de méthodes ont été testées : la première, externe, où l'émetteur est placé sur le dos du poisson en dessous de la nageoire dorsale à travers la musculature, et la seconde, interne, où l'émetteur est placé dans la cavité péritonéale. Vingt-cinq poissons ont été observés sur une période de deux semaines concernant le taux de survie, la cicatrisation post-chirurgicale, la présence ou non de blessures et le comportement post-opératoire. Même si nous avons observé un taux de survie de 100 \% pour les deux groupes et n'avons pas observé de modification de la flottabilité ou de la nage, les conclusions de cette étude indiquent que les deux groupes de poissons ont été affectés par la présence de l'émetteur de manière différente. Les poissons avec une marque externe sont affectés de manière chronique, entraînant un impact physique. Quant aux poissons avec une marque dans la cavité péritonéale ils présentent des effets de courtes durées (moins de $36 \mathrm{~h}$ ), qui peuvent être attribué à la chirurgie et ne sont pas sujet au fouling sur l'émetteur ni à une abrasion des blessures due au frottement du poisson. De plus, ils semblent récupérer plus rapidement, sans indication d'effets à long terme. Sur base des conclusions de cette étude nous recommandons l'utilisation de la méthode d'implantation intrapéritonéale pour marquer la saupe.

(C) 2003 Éditions scientifiques et médicales Elsevier SAS and Ifremer/CNRS/IRD. All rights reserved.

Keywords: Sarpa salpa; Sparidae; External attachment; Intraperitoneal implantation; Telemetry

Mots clés : Sarpa salpa ; Sparidae ; Attachement externe ; Implantation intrapéritonéale ; Télémétrie

* Tel.: +32-4-366-5018; fax: +32-4-366-5093.

E-mail address: catherine.jadot@ulg.ac.be (C. Jadot). 


\section{Introduction}

In recent decades, telemetry studies have provided important information on the home range, habitat selection and behaviour of fish in the wild (Stasko and Pincock, 1978). Three types of transmitter attachments are frequently used to tag fish: stomach insertion, external attachment and surgical implantation. For a given species with distinct anatomy and behaviour in a particular environment, the transmitter attachment method should be the technique that affects the fish the least. As no information was available for the tagging of the strepie, Sarpa salpa (L.), a suitability study of attachment techniques was needed. This small herbivorous Sparidae is commonly found throughout the Mediterranean and on the Eastern Atlantic coast (from the Golf of Gascogne to South Africa and around Madeira, the Azores and the Canary Islands), and is occasionally found in the Black Sea and on the Eastern coast of Africa (Bauchot and Hureau, 1990). The strepie is of commercial interest locally, e.g. in the Canary Islands, where it constitutes one of the most important fishes taken by the local artisan fleet (Méndez-Villamil et al., 2002). Moreover, in the Mediterranean Sea, S. salpa has a key ecological role as main vertebrate grazer of endemic Posidonia oceanica (L.) meadow (Peirano et al., 2002).

In this study, the external attachment and surgical implantation were evaluated. The stomach insertion of transmitter, mostly developed for anadromous fishes non-feeding during their migration, is not suitable for $S$. salpa, characterised by a small mouth and year-round feeding. Both techniques have been successfully employed for many years in different studies (external attachment: e.g. Marsac and Cayré, 1998; Bégout-Anras et al., 1999; surgical implantation: e.g. Beddow and McKinley, 1998; Ovidio et al., 1998). The external attachment of a transmitter can be performed rapidly and easily (Ross and McCormick, 1981; Urquhart and Stewart, 1993), but may cause balance modifications, increase drag and can be responsible for irregular swimming (Thorpe et al., 1981). Furthermore in the long run, the drag may result in the erosion of dorsal muscles (Baras, 1992), whereas the intraperitoneal implantation requires practice, more time and complete anaesthesia of the fish (Moore et al., 1990; Thoreau and Baras, 1997). Nevertheless, in surgical insertion in the body cavity, the transmitter is closer to the centre of gravity of the fish and causes less interference with swimming and longterm growth (Baras and Lagardère, 1995).

Moreover, the loss of tag in both external attachment and internal insertion has been reported in several studies. Ross and McCormick (1981), for example, reported that "dummy radio tagged yellow perch (Perca flavescens) had lost their tag, holes were evident where the attachment wires had pulled through the body and the dorsal fin". Also, the expulsion of transmitters through the incision and by other routes has been observed in high percentages $(9-71 \%)$ for several species, like the Atlantic salmon (Salmo salar) (Moore et al., 1990) and the bluegills (Leptomis macrochirus) (Knights and Lasees, 1996).
In order to study the behavioural ecology of $S$. salpa in the field via biotelemetry methods, for management of resources or design of protected areas, this work is aimed to determine the most adequate method of transmitter attachment on this species.

\section{Materials and methods}

Twenty-five S. salpa, caught in the Western Mediterranean Sea, were used for this study $(218 \pm 29 \mathrm{~mm}$ FL, $199 \pm$ $78 \mathrm{~g}$ ), 10 for external attachment and 15 for tag surgical implantation Table 1.

During the experiment, the fish were held under natural photoperiod conditions, at a water temperature of $19 \pm 1{ }^{\circ} \mathrm{C}$. A weekly control of the phosphate, nitrite and nitrate rates and of salinity was made to ensure that there were no chemical modifications to tank water. As the strepie is a difficult fish to catch and is not available farmed, this research was conducted in three distinct time periods, depending on fish availability. Three tanks were used for the experiment: A, B and $\mathrm{C}, 1.2 \mathrm{~m}^{3}(225 \mathrm{~cm} \times 80 \mathrm{~cm} \times 70 \mathrm{~cm}), 5 \mathrm{~m}^{3}(380 \mathrm{~cm} \times$ $110 \mathrm{~cm} \times 120 \mathrm{~cm})$ and $3 \mathrm{~m}^{3}(300 \mathrm{~cm} \times 100 \mathrm{~cm} \times 100 \mathrm{~cm})$, respectively. According to the tank availability in the lab at the moment the fish arrived, they were distributed in the three experimental tanks as shown in Table 1. All the fish were held in their respective experimental tanks at least 2 weeks before

Table 1

Characteristics of the experimented fish. TBWR is transmitter to body weight ratio in air, $\mathrm{I}$ is an implantation and $\mathrm{E}$ an external attachment of the transmitter. Tank A is $1.2 \mathrm{~m}^{3} ; \mathrm{B}, 5 \mathrm{~m}^{3}$ and $\mathrm{C}, 3 \mathrm{~m}^{3}$

\begin{tabular}{|c|c|c|c|c|c|}
\hline Fish & $\begin{array}{l}\text { Length } \\
(\mathrm{FL}, \mathrm{mm})\end{array}$ & $\begin{array}{l}\text { Weight } \\
\text { (g) }\end{array}$ & $\begin{array}{l}\text { TBWR } \\
(\%)\end{array}$ & $\begin{array}{l}\text { Type of } \\
\text { attachment }\end{array}$ & Tank \\
\hline 1 & 291 & 326 & 1.2 & I & A \\
\hline 2 & 245 & 282 & 1.4 & I & A \\
\hline 3 & 269 & 350 & 1.1 & I & A \\
\hline 4 & 191 & 139 & 2.9 & I & A \\
\hline 5 & 189 & 135 & 3.0 & I & A \\
\hline 6 & 202 & 137 & 2.9 & I & B \\
\hline 7 & 230 & 220 & 1.8 & I & B \\
\hline 8 & 238 & 273 & 1.5 & I & B \\
\hline 9 & 225 & 197 & 2.0 & I & B \\
\hline 10 & 213 & 150 & 2.7 & I & B \\
\hline 11 & 215 & 168 & 2.4 & I & B \\
\hline 12 & 265 & 370 & 1.1 & I & B \\
\hline 13 & 255 & 310 & 1.3 & I & B \\
\hline 14 & 197 & 139 & 2.9 & I & B \\
\hline 15 & 198 & 138 & 2.9 & I & B \\
\hline 16 & 214 & 172 & 2.3 & $\mathrm{E}$ & A \\
\hline 17 & 190 & 140 & 2.9 & $\mathrm{E}$ & A \\
\hline 18 & 197 & 132 & 3.0 & $\mathrm{E}$ & A \\
\hline 19 & 201 & 140 & 2.9 & $\mathrm{E}$ & A \\
\hline 20 & 195 & 133 & 3.0 & $\mathrm{E}$ & A \\
\hline 21 & 192 & 138 & 2.9 & $\mathrm{E}$ & $\mathrm{C}$ \\
\hline 22 & 225 & 220 & 1.8 & $\mathrm{E}$ & $\mathrm{C}$ \\
\hline 23 & 197 & 173 & 2.3 & $\mathrm{E}$ & $\mathrm{C}$ \\
\hline 24 & 189 & 132 & 3.0 & $\mathrm{E}$ & $\mathrm{C}$ \\
\hline 25 & 240 & 269 & 1.5 & $\mathrm{E}$ & $\mathrm{C}$ \\
\hline
\end{tabular}


experimentation to ensure full recovery from stress of capture and transport. They were fed every $24 \mathrm{~h}$ with salad, chopped mussels and shrimp. The transmitters used in the study were epoxy dummy transmitters (without working components), similar in weight and size to the commercially available transmitters $(26 \mathrm{~mm} \times 8 \mathrm{~mm}, 4 \mathrm{~g}$ in air). The transmitter to body weight ratios in air (TBWR) were slightly higher than the generally recommended $2 \%$ for field telemetry studies (Winter, 1983): they represented no more than $3 \%$ of the fish's body weight (in air) Table 1. Given the actual availability of the acoustic transmitter on the market, it would have been difficult, due to the average size and weight of the strepie, to obtain a TBWR under $2 \%$ and keep a reasonable lifetime of the transmitter. Moreover, Mellas and Haynes (1985) and Moore et al. (1990) increased the TBWR up to $2.8 \%$ and $3.3 \%$ and found no effect of intraperitoneal implantation on either swimming performance or growth of the tested fish. Likewise, Adams et al. (1998) recommend for field studies that the maximum TBWR should be no greater than $5 \%$. More recently, the $2 \%$ rule was challenged by Brown et al. (1999); they found that swimming performance of the rainbow trout Oncorhynchys mykiss was not affected by the presence of transmitters with a TBWR ranging from $6 \%$ to $12 \%$.

Fish were removed from the tank and anaesthetised in a $0.2 \mathrm{mg} \mathrm{l}^{-1} 2$-phenoxy-ethanol solution. When the fish were fully anaesthetised, showing no reaction to external stimuli (5-10 $\mathrm{min}$ ) they were weighed (to the nearest $0.1 \mathrm{~g}$ ), measured (Fork Length in mm), and placed in a V-shaped Plexiglas support, adjusted to their morphology. This allowed all the fish to be fully under water during tagging except for the ventral or the dorsal side, depending on the tagging method.

For external attachment, the dummy transmitter was positioned on the dorsal side of the fish below the dorsal fin by means of two threads sutured through the dorsal musculature. The wires used were made of stainless steel core sheathed with kevlar (tensile strength $3.0 \mathrm{~kg}$ ). A drop of cyanoacrylic glue was put on the knots to consolidate them. To reduce abrasion, rubber pads ( $2 \mathrm{~mm}$ thick and same size of the transmitter) between the tag and the epidermis were placed as recommended by Matthews et al. (1990). A similar rubber pad was attached on the opposite side Fig. 1 to avoid erosion from the wires.

For surgical implantation, transmitters cleaned in Polyvidon iodine were inserted in the peritoneal cavity. All care was taken to minimise infection, the amount of handling, air exposure time and to ensure that no internal organs were damaged, as recommended by Martinelli et al. (1998). The incision (20-25 mm long) on the mid ventral-line, 20-25 mm before the anus, was closed with two individual sutures using a sterile plain catgut $(2.0 \mathrm{dm})$ on cutting needles. Both procedures took no more than $7 \mathrm{~min}$.

One by one, the fish were transferred to a recovery bucket (80 1), where they were observed continually until the effects of the anaesthesia had disappeared. When full equilibrium

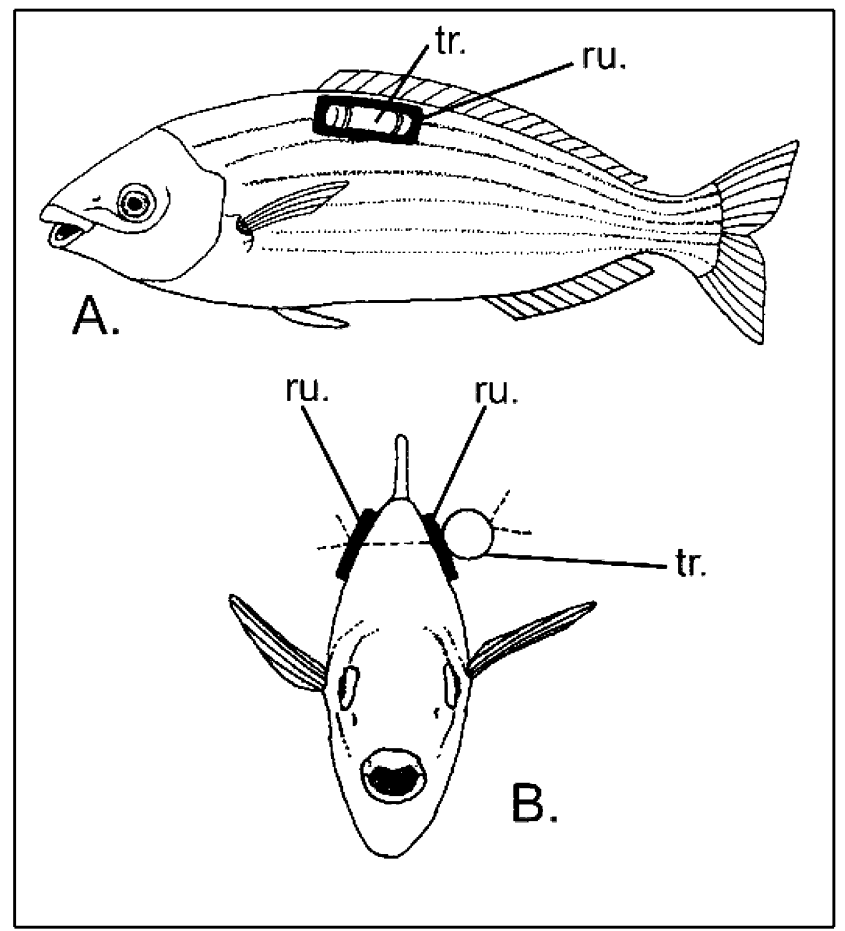

Fig. 1. Method used to fix the external transmitter with protective rubber pads on $S$. salpa. (A) Lateral view. (B) Frontal view. Ru is rubber pad and tr is transmitter.

was regained and the fish reacted to external stimuli (3$5 \mathrm{~min}$ ) the fish was returned to the original experimental tank.

The fish were monitored by direct observation over a 14-d period for survival, surgical healing, occurrence of injury and post-tagging behaviour.

At the end of the experiment, all fish were euthanised with an overdose of 2-phenoxy-ethanol and autopsied. For the internal implantation, incisions were inspected externally for evidence of infection and healing, and the fish were then dissected and examined for inflammation of the tissue and organs and transmitter position. For the external attachment, the fixation points were examined for indication of chafing, abrasion or ulcerated wounds.

\section{Results}

In both experiments, we recorded $100 \%$ survival of fish. Based on direct observational data, 12-36 h after tagging, the fish returned to behaviour and feeding as observed before tagging. The criteria used were: mobility, frightening, appetite and general stress symptoms. For both groups of fish, after the recuperation period, i.e. (3-5 $\mathrm{min})$ spent in the recovery bucket, buoyancy was not noticeably modified, as tagged fish were able to stay motionless in the water column and no irregular swimming was observed.

After $14 \mathrm{~d}, 100 \%$ of the fish with external dummy transmitters had mild to severe injuries around the transmitter Table 22. This was attributed to the fish rubbing against rocks or substrate scrapping in the tank. Indeed, during direct 
Table 2

Type of injuries (mild, medium or severe) and fouling (Y: yes, N: no) on the externally tagged $S$. salpa

\begin{tabular}{lll}
\hline Fish & Injuries & Fouling \\
\hline 16 & Mild & Y \\
17 & Severe & N \\
18 & Medium & Y \\
19 & Medium & N \\
20 & Medium & Y \\
21 & Medium & Y \\
22 & Mild & Y \\
23 & Mild & Y \\
24 & Severe & N \\
25 & Medium & Y \\
\hline
\end{tabular}

observations on several occasions, several individuals with external transmitter were remarked to rub and chafe against the rocks and the substrate by repeated impacts. On seven transmitters out of 10, fouling had begun Table 2. The fouling was not important and did not increase tag shedding. However, the duration of the study was short and over a longer period this parameter should be taken into consideration.

After $14 \mathrm{~d}$, the incisions on the implanted fish were well healed, and most of the suture sites were absorbed. We observed no transmitter loss and no indication that the process of expulsion had begun. Infection was not observed in any of the fish.

After autopsy of the fish, all the transmitters were encapsulated in fibrous tissue, or the process had started. No infection of the incision was noticed. Moreover, there was no evidence of tissue damage in any fish.

\section{Discussion}

For a given species in a particular environment, the success and the harmlessness of transmitter attachment are highly specific. The transmitter attachment method selected should be the technique that affects the fish the least. Even if we observed a $100 \%$ survival rate, this suitability study of attachment technique demonstrated that the two techniques did not affect the fish in the same way.

In both cases, the general behaviour, swimming ability, buoyancy and feeding behaviour were unaffected. The fouling found on the external transmitters was not important, but the duration of the study was short and the fouling might not be so negligible after several weeks. More studies are needed to describe the potential negative long-term effects that fouling might have. Thorstad et al. (2001) pointed out that fouling can be extreme in certain cases and the effects underestimated. They found green algae, mussels, seaweed and Balanus sp. on the external transmitter and the antenna of a tagged Atlantic salmon (Salmo salar). The fish was slim, had no fat deposit and seemed to be in a poor condition, probably because of the additional weight of the transmitter and the antenna.
Expulsion of transmitters through the incision or by other routes has been reported in high percentages $(9-71 \%)$ for several species (Moore et al, 1990; Knights and Lasees, 1996). In other species, transmitters retention over an extended period is high (Thoreau and Baras, 1997). In the present study, we observed no transmitter loss and no indication that the process of expulsion had begun. Nevertheless, the time of the experiment could have been too short for detection of expulsion process, which generally starts after a longer period of time (e.g. $121 \mathrm{~d}$ for the Atlantic salmon, Salmo salar, Moore et al., 1990). Although no external transmitters were lost during this experiment, this has been reported in several studies (e.g. Ross and McCormick, 1981). Rock chafing and substrate scraping, as was observed in this study for the external tagged $S$. salpa, probably caused the tag loss.

If tagged fish are unable to preserve the same buoyancy as untagged fish, then the physiology and behaviour of tagged fish may be influenced. For both groups of fish, buoyancy was not noticeably modified, showing the ability of $S$. salpa to compensate for the decrease in buoyancy with swimming movements or by filling their air bladders (Gallepp and Magnuson, 1972).

In some studies (Thorpe et al., 1981; Mellas and Haynes, 1985), the external transmitter attachment was responsible for irregular swimming, but this was not the case in this study with $S$. salpa. Even if both groups had no noticeable buoyancy or swimming alteration, the findings here indicate that both groups of tagged fish were affected by the presence of the transmitter in a different way. On one hand, fish with an external transmitter would be chronically affected, incurring physical impact. On the other hand, surgically implanted fish exhibited short-term tagging effects attributable to surgery effects (less than $36 \mathrm{~h}$ ), but were not subject to fouling on transmitter or wound chafing and appeared to recover quickly with no indication of long-term effects.

Moreover, as the herbivorous strepie lives close to the vegetation it eats, external transmitters may get entangled in this vegetation, as was shown for the perch, Perca flavescens (Ross and McCormick, 1981) or for the pike, Esox lucius, (Lucas et al., 1993). Furthermore, S. salpa is a gregarious fish and its behaviour includes close contact with other fish, which could lead to important chafing. And finally, in the fieldwork, fish with external transmitters may be more predation-prone, as the shape and the colour of the tag may influence predation risk (Baras and Lagardère, 1995), or may decrease the tagged fish's ability to perceive and escape from a predator (Ross and McCormick, 1981).

Based on the findings of this study, the use of the surgical implantation method for $S$. salpa is recommended. Using the lightest anaesthesia level that allows completion of the procedure would greatly reduce recovery time. Also, we suggest releasing the tagged $S$. salpa immediately after full recovery from anaesthesia. This will avoid trauma due to long postoperative care. Direct release has proven to be far more effective for steelhead trout, Salmo gairdneri, and Oncorhyn- 
chus spp. (Mellas and Haynes, 1985). In addition, Otis and Weber (in Lucas and Baras, 2000) recommend direct release to prevent any damaging effect of captivity on fish health and behaviour.

\section{Acknowledgements}

Support for this paper was provided by a Ph.D. research grant from FRIA (Fonds pour la Formation à la recherche dans l'Industrie et l'Agriculture) to the author. The author wishes to thank the anonymous referees for their relevant comments and suggestions. This paper is a MARE publication (MARE 018).

\section{References}

Adams, N.S., Rondorf, D.W., Evans, S.D., Kelly, J.E., 1998. Effects of surgically and gastrically implanted radio transmitters on swimming performance and predator avoidance of juvenile Chinook salmon (Oncorhynchus tshawytscha). Can. J. Fish. Aquat. Sci. 55, 781-787.

Baras, E., 1992. Etude des stratégies d'occupation du temps et de l'espace chez le barbeau fluviatile, Barbus barbus (L.). Cahiers d'Ethologie 12, $125-442$.

Baras, E., Lagardère, J.P., 1995. Fish telemetry in aquaculture: review and perspectives. Aqua. Inter. 3, 77-102.

Bauchot, M.L., Hureau, J.C., 1990. Sparidae. In: Quero, J.C., Hureau, J.C., Karrer, C., Post, A., Saldanha, L. (Eds.), Check-list of the fishes on the Eastern Tropical Atlantic, Clofeta II. UNESCO, Paris, pp. 790-812.

Beddow, T.A., McKinley, R.S., 1998. Effects of thermal environment on electromyographical signals obtained from Atlantic salmon (Salmo salar L.) during forced swimming. Hydrobiologia 371/371, 232-255.

Bégout-Anras, M.L., Gyselman, E.C., Jorgenson, J.K., Kristofferson, A.H., Anras, L., 1999. Habitat preferences and residence time for the freshwater to ocean transition stage in Artic charr. J. Mar. Biol. Ass. UK 79, $153-160$.

Brown, R.S., Cooke, S.J., Anderson, W.G., McKinley, R.S., 1999. Evidence to challenge the " $2 \%$ rule" for biotelemetry. N. Am. J. Fish. Manage. 19, 867-871.

Gallepp, G.W., Magnuson, J.J., 1972. Effects of negative buoyancy on the behavior of bluegill Lepomis macrochirus Rafinesque. Trans. Am. Fish. Soc. 101, 507-512.

Knight, B.C., Lasees, B.A., 1996. Effects of implanted transmitters on adult bluegills at two temperatures. Trans. Am. Fish. Soc. 125, 440-449.

Lucas, M.C., Johnstone, A.D.F., Priede, I.G., 1993. Use of physiological telemetry as a method for estimating, metabolism of fish in the natural environment. Trans. Am. Fish. Soc. 122, 822-833.
Lucas, M.C., Baras, E., 2000. Methods for studying spatial behaviour of freshwater fishes in the natural environment. Fish and Fish. 1, 283-316.

Marsac, F., Cayré, P., 1998. Telemetry applied to behaviour analysis of yellowfin tuna (Thunnus albacares, Bonnaterre, 1788) movements in a network of fish aggregating devices. Hydrobiologia 371/372, 155-171.

Martinelli, T.L., Hansel, H.C., Shively, R.S., 1998. Growth and physiological responses to surgical and gastric implantation technique in subyearling chinook salmon (Onocorhynchus tshawytscha). Hydrobiologia 371/372, 79-87.

Matthews, K.R., Quinn, T.P., Miller, B.S., 1990. Use of ultrasonic transmitters to track demersal rockfish movement on shallow rocky reefs. Am. Fish Soc. Symp. 7, 375-379.

Mellas, E.J., Haynes, J.M., 1985. Swimming performance and behaviour of rainbow trout (Salmo gairdneri) and white perch (Morone americana): effects of attaching telemetry transmitters. Can. J. Fish. Aquat. Sci. 42, 488-493.

Méndez-Villamil, M., Lorenzo, J.M., Pajuelo, J.G., Ramos, A., Coca, J., 2002. Aspects of the live history of the salema, Sarpa salpa (Pisces, Sparidae), of the Canarian Archipelago (central-east Atlantic). Env. Biol. Fish. 63, 183-192.

Moore, A., Russell, I.C., Potter, E.C., 1990. The effects of intraperitoneally implanted dummy acoustic transmitters on the behaviour and physiology of juvenile Atlantic salmon, Salmo salar L. J. Fish Biol. 37, 713-721.

Ovidio, M., Baras, E., Goffaux, D., Briles, C., Philippart, J.-C., 1998. Environmental unpredictability rules the autumn migrations of trout (Salmo trutta) in the Belgian Ardennes. Hydrobiologia 371/372, 262273.

Peirano, A., Niccolai, I., Mauro, R., Bianchi, C., 2002. Seasonal grazing and food preference of herbivores in a Posidonia oceanica meadow. Sci. Mar. 65 (4), 367-374.

Ross, M.J., McCormick, J.H., 1981. Effects of external radio transmitters on fish. Prog. Fish Cult. 43 (2), 67-72.

Stasko, A.B., Pincock, D.G., 1978. Review of underwater biotelemetry, with emphasis on ultrasonic techniques. J. Fish. Res. Bd. Can. 34, 1261-1285.

Thoreau, X., Baras, E., 1997. Evaluation of surgery procedures for implanting telemetry transmitters into the body cavity of Tilapia Oreochromis aureus. Aquat. Living Res. 10, 207-211.

Thorpe, J.E., Ross, L.G., Struthers, G., Watt, W., 1981. Tracking Atlantic salmon (Salmo salar L.) smolts through Loch Voil, Scotland. J. Fish Biol. 9, 519-537.

Thorstad, E.B., Okland, F., Heggberget, T.G., 2001. Are long term negative effects from external tags underestimated? Fouling of an external attached telemetry transmitter. J. Fish Biol. 59, 1092-1094.

Urquhart, G.G., Stewart, P.A.M., 1993. A review of techniques for the observation of fish behaviour in the sea. ICES Mar. Sci. Symp. 196, 135-139.

Winter, J.D., 1983. Underwater biotelemetry. In: Nielsen, L.A., Johnsen, D.L. (Eds.), Fisheries Techniques. American Fisheries Society, Bethesda, Maryland, USA, pp. 371-395. 